\title{
Communication strategies for strengthening the parent-teacher relationships in the primary schools
}

\author{
Popovska, Nalevska Gorica $\$ \\ International Slavic University “Gavrilo Radomir” - Bitola, Macedonia (popovska.g@gmail.com) \\ Popovski, Filip \\ University St. Kliment Ohridski - Bitola, Macedonia (filip.popovski@tfb.uklo.edu.mk) \\ Dimova, Popovska Hristina \\ University St. Kliment Ohridski - Bitola, Macedonia (hristinadimova95@gmail.com)
}

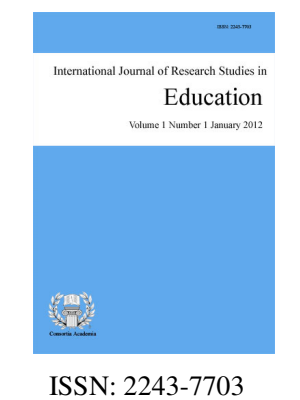

OPEN ACCESS

\section{Abstract}

Parent involvement is consistently ranked high among the key components of effective schools, and as a result it is one of the brightest prospects for the future of public education. This study aims at finding out attitudes and opinions of elementary teachers and parents about their cooperation and communication strategies in primary schools in the Republic of North Macedonia. Research questions highlight the relationship between parents and schools, parental support, communication strategies, parental recognition program curriculum and functioning of the partnership between parents and schools. The study used descriptive research method and structured questionnaire for teachers and parents in primary schools. The was research conducted on 371 parents and 50 teachers, showed that parents and teachers are satisfied with their mutual cooperation. Although both believe that the cooperation between the school and the family will improve if different communication strategies are used, the traditional ones are still dominant, one-way communication dominates, and the direct participation of parents and their feedback in the organization and realization of school events and activities is neglected. The ways of communication are primarily aimed at transmitting information to parents, and less common are those that provide an opportunity for active engagement of parents, using their knowledge, skills and experiences as an important resource that can contribute to school openness and building partnership with the school. Furthermore, this study provides recommendation for strengthening the parent-teacher communication and fostering partnerships with parents.

Keywords: communication, strategies, parents, teachers, primary school 


\section{Communication strategies for strengthening the parent-teacher relationships in the primary schools}

\section{Introduction}

The best way to avoid misunderstanding between parents and teachers is to have regular, clear, established lines of communication. The more informed and involved parents are with what is going on in the classroom, the more they feel as a part of the classroom team (Bender, 2005). Informed parents who feel included on a regular basis are more likely to be supportive and understanding and less likely to jump to negative conclusions. The greatest beneficiary of the rewards of a positive parent-teacher partnership is the child. When parents and teachers work together in the best interests of the child, an environment is created with optimal potential for learner development (Fuller, 1999). Parent involvement in primary school encompasses a wide variety of parent behavior patterns and practices and cannot be defined by one specific feature. Parent involvement in primary school is multidimensional and can include parent's aspirations, expectations, interests, attitudes and beliefs regarding education, as well as parent's participation in school activities at school and at home (Hong \& Ho, 2005)

In their study on parent involvement, Vandergrift and Greene (1992) identified four categories to explain parent involvement with regard to the support/participation they present in the learning of their children: parents who are committed to their children but do not participate, those who participate but are not necessarily supportive, parents that supports and participate, and parents who neither support nor participate in their child's education. In rethinking parent involvement, primary schools might better evaluate the degree of involvement by separating the notions of support and participation of the four basic types of parents in order to understand the level of commitment and active participation. Both support and participation fall along a continuum of involvement.

Parents who are supportive and willing to participate are likely to attend workshops and conferences, respond to notes and phone calls and get involved in decision-making roles through the governing body and planning teams. Even though some parents care deeply about their child's education, they do not participate in school activities. For them, several kinds of approaches hold promise. Newsletters with suggestions for home activities have proven to be successful, as have school-based activities where they feel safe in numbers and meeting parents on their own turf. The most difficult parent to identify is the one who attends school events but is not supportive at home. This type of parent may attend a parent-teacher conference only to go home and ignore or mistreat the child.

Unsupportive and non-participative parents are the most difficult to reach, but it is perhaps the most important group on which to focus efforts to improve communication. It is essential to determine the basis for their lack of involvement. In many cases, the reasons stem from the fact that the parents own problems take precedence over his or her children's education (Vandergrift \& Greene, 1992).

A number of studies have confirmed this prediction: parental involvement in children's schooling appears to be associated with a range of positive outcomes, including fewer behavioral problems and better social conduct (El Nokali et al., 2010; Mashburn et al., 2011; Powell et al., 2010), lower dropout rates (McNeal, 1999) and higher student achievement (Arnold et al., 2008; Marcon, 1999; Powell et al., 2010). Literature generally shows that parent-teacher contact and parents' participation in school activities improve social and academic outcomes. Most of these studies have been focused on school-aged children; however, the relationship between school and family emerges as a relevant theme since early childhood in particular when the child attends a child-care centre (Shpancer, 1997). In fact, recent studies point strongly to the importance of the earliest years of a child's life as a critical period for developing the basis for further learning. 
Benefits to parent involvement go beyond increasing student achievement. Parent involvement in a child's school has been shown to improve student attendance, behavior, homework completion, and grades. "When schools have well-developed partnership programs, families become involved and students become more positive about school and learning" (Epstein, 2005).

While parent involvement is critical to student success, the role of the classroom teacher cannot be overstated (Ripley, 2010). Teacher efficacy is positively related to student performance (Dembo \& Gibson, 1985). In an elementary school, a child's classroom teacher makes an enormous amount of difference in what that child learns or does not learn during a school year. "Parents have always worried about where to send their children to school; but the school, statistically speaking, does not matter as much as which adult stands in front of their children" (Ripley, p. 4). Top teachers have five tendencies in common: constantly reevaluating their practices, recruiting students and families into the learning process, maintaining consistent focus on keeping student learning as the priority, planning thoroughly and purposefully, and refusing to surrender to the combined menaces of poverty, school bureaucracy, and school budgetary problems (Ripley, 2010). It is a challenge for schools to determine what specifically makes the difference in establishing positive relationships with parents. It may not be as simple as increasing the number of hours parents are involved in helping their children at home or at school. Kohl et al. (2000) reported "the quality of the parent-teacher relationships was more strongly associated with positive child outcomes than was the amount of involvement" (p. 517). Ultimately, many educators want to understand how to most effectively make use of the parents of their students.

Parent involvement can also impact teacher behavior and attitudes. A 2004 study found that teachers believed parents who volunteered at school cared more about their child's education than parents who did not volunteer at school (Hill \& Taylor). Teachers may also pay more attention to children whose parents are involved in the school (Grolnick \& Slowiaczek, 1994). Additionally, teachers" attitudes about teaching changed when parents were involved in the school (Epstein \& Van Voorhis, 2001). "Research shows that family involvement also benefits teachers. They report more positive feelings about teaching and about their schools when there is more parent involvement in the school" (p. 185).

Effective schools provide parents the opportunity to participate in and support their child's education (Goldring \& Sullivan, 1996). Schools willing to partner with families can provide parents with opportunities to improve their children's educational experience (Epstein, 2001; Sheldon, 2003; Epstein \& Jansorn, 2004; Payne, 2008). Creating a welcoming atmosphere is an important component to making parents feel welcomed in the school (Epstein, 2004). This includes introducing parents to the school's culture and providing them opportunities to participate in different activities (Goldring \& Sullivan, 1996). Epstein (2001) reported the following: Some students, including those who are at risk of failing, presently succeed in school because their parents, teachers, friends, and others in the community communicate well with each other and help students focus on their attendance, classwork, homework, and other important behaviors. More students, especially those who are at risk of failing, need this kind of coordinated support so that they too have a better chance to succeed in school (p. 166).

Schools, however, may not be well versed in how to involve parents. "The problem is not a lack of desire for parent involvement; the problem is that most schools are unsure how to involve parents and how to translate parent involvement into student achievement" (Ingram, et al., 2007, p. 480). Hoover-Dempsey, et al. (2005) created a list of strategies designed to increase schools' capacities for involving parents in their children's education:

$>$ Create an inviting school climate.

$>$ Empower teachers for parental involvement.

$>$ Learn about parents' goals, perspectives on child's learning, family circumstances, and culture. 
$>\quad$ Join with existing parent-teacher-family structures to enhance involvement.

$>\quad$ Offer full range of involvement opportunities, including standard approaches (parent-teacher conferences, student performances) and new opportunities unique to school and community (e.g., first-day-of-school celebrations, parent workshops, social/networking events).

$>$ Invite teachers, parents, principal, and staff to student-centered events at school.

Communication is often complicated by an inability to accurately interpret communication. Misinterpretation results in inappropriate responses which may create serious and sometimes long-lasting difficulties flowing from communication distortion. The way to prevent such misunderstandings is to understand and implement effective communication strategies (Bender, 2005).

\subsection{Strategies in building effective communication}

Teachers strive to establish partnerships with parents to support students' learning. Effective communication is fundamental to this partnership and building of a sense of sharing between home and school (Ozmen, Akuzum, Zincirli \& Selcuk, 2016). In these changing times, effective partnerships between teachers and parents become even more essential to meet the needs of the children they share. Epstein (1995) describes communicating with parents as one of the six major types of parent involvement practices critical to establishing strong working relationships between teachers and parents. Cultivating the parent-teacher relationship is also considered vital to the development of schools as teaching communities (Schussler, 2003). Many teachers are however not specifically trained in the skills they need to communicate effectively with parents (Lawrence-Lightfoot, 2004). Because school communication practices are so fundamental to involving families in the education process, Caspe (2003) suggests that teachers' preparation and professional development programs should actively promote the development of communication skills for teachers. Effective communication in school begins with the welcome sign when parents enter the school building (Chambers, 1998). Welcome signs reflecting the range of ethnic languages spoken in the school community create an even more inviting atmosphere (Lai \& Ishiyama, 2004). The next impression may be the welcoming smile from the first person with which the visitor interact on the school premise or, conversely, lack of acknowledgement by office staff. Expressed communication involves one-way or two-way exchanges (Bender, 2005). One-way communication occurs when teachers seek to inform parents about events, activities, or learner progress through a variety of sources, such as an introductory letter at the beginning of the school year, classroom or school newsletters, report cards, communication books, and school web sites. Two-way communication involves interactive dialogue between teachers and parents. Conversations may occur during telephone calls, home visits, parent-teacher conferences, open houses, and various school-based community activities. Teachers should actively incorporate both strategies to maximize sharing information with parents.

One-way communication - Written communication with regard to the formal school environment comprises a one-way communication and is probably the most efficient and effective way schools can provide valuable ongoing correspondence between school and home. Written communication is a permanent product that requires careful consideration regarding format and content. The goal is to organize concise, clear and accurate information so that parents will read and understand it.

Newsletters are commonly used as mechanism to share written information with the parent community. Consistent application of several specific strategies can make classroom and school newsletters even more effective communication tools. Stakeholders should incorporate the same color, quality, and paper size for all newsletters to create a communication set of importance in everyday language and ensure grammar, spell checks and proofreading of the information (Aronson, 1995). Chambers (1998) further proposes that schools develop a descriptive brochure to provide helpful information for new families moving into the school community.

School-to-home notebooks are another commonly used written communication technique. Many teachers 
use daily communication books to share information with parents, particularly for children who have special learning needs (Davern, 2004). Initially, it is important to clearly establish what information will be communicated, by whom and how often. Teachers should be sensitive to a balance of good and bad news contained in the message.

Davern (2004) notes that it is important to consider when a face-to-face meeting is more appropriate than a written exchange, depending on the issue. A parent's non-verbal reaction to a message (such as, agreement, surprise, boredom, and hostility) can tell teachers how to respond and it allows immediate indications of how a message is being received. Participants involved can discuss the message, ask questions for clarification and resolve any misunderstandings.

Report cards are the traditional method of conveying permanent, written evaluative information regarding the learner's progress. Report cards should be clear and easy for parents to understand. These records should provide an analysis of academic development across content areas, information about learners' strengths and learning styles, an assessment of the child's social development, specific goals for the learner to work on, and associated suggestions for the parent (Aronson, 1995). Report cards also generally provide an invitation for the parent to respond, usually in written form. Teachers should review parents' responses in timely matter to determine any required follow-ups. Carefully prepared report cards, coupled with parent conferences as needed, provide effective communication with parents by ensuring that the report card is not the first communication when concerns exist. Rather, frequent progress reports, phone calls, and/or e-mail messages should support and improve learner performance prior to the traditional report card (Giannetti \& Sagarese, 1998).

Two-way communication - A two-way communication occurs when teachers and parents dialogue together. Effective dialogue develops out of a growing trust, a mutuality of concern, and an appreciation of contrasting perspectives. Teachers should strive to make these interactions as productive as possible. One communication strategy is a phone call home. Love (1996) advocates the use of "good news calls" to recognize the child for progress or a job well done as a way of promoting positive relations with parents.

Another traditional occasion for a dialogue is the parent-teacher conference. Effective parent-teacher conferences are an opportunity to create a successful partnership, but they may be anxiety provoking for both teachers and parents alike (Minke \& Anderson, 2003). In this regard, Metcalf (2002) suggests that instead of viewing the conference as a reporting session for what is not working in school, teachers could construct an opportunity to discuss what is working with the learners. Metcalf (2002) advocates a solution-focused approach based on past learner successes in order to alleviate blame and move forward with an individualized intervention plan. Putting the child at the centre of the parent-teacher conferences require thoughtful and well-developed planning. In planning for the conference, encourage teachers to select an appropriate meeting time and location, advise the participants in advance, review the learners' file in advance, develop a clear purpose for the meeting and identify information to be discussed including positive aspects of the child's performance. Teachers are advised to begin the conference with a friendly comment and brief, informal conversation and then to explain the learner's progress in a straightforward way, carefully listening to parent's input and ensuring time to summarize the discussion and plan recommendations for future planning. Establishing a specific time frame at the outset of the conference, followed by close adherence to the agenda, provides more comfortable termination of the meeting. Teachers are encouraged to follow up the meeting by preparing a written conference summary in line with school board policies. Additional follow-up activities might involve making appropriate referrals, discussions with relevant teachers, or planning specific instructions or strategies. (Lawrence-Lightfoot, 2003).

Advisory corner for parents - a room in the school where parents can talk to each other and to teachers about issues of common interest or read literature with educational content. Open days for parents when they can be informed about everything they need and interest, which refers to the problems, conditions, achievements of their children, but also the opportunity to get directly acquainted with the school climate. Providing suggestions and ideas for home conditions that support children's development end education, through workshops, videotapes and 
computerized phone messages, providing parent education and other courses or training for parents such as family literacy, directing families to support programs for children's development. Teacher's visit in the parental home. The visit enables the teacher to get directly acquainted with the material, cultural, health and psychological conditions of the family, which will help him in solving possible problems in the upbringing and behavior of the student.

Communication through technology - In recent years, teachers have experimented with various technologies to communicate with parents in innovative and time-efficient ways. Integrating technology can help schools communicate quickly to a broad parent community (Ramirez, 2001). Classroom phones and voice mail, video technology and school web sites are all examples of integrating technology. Phones in each classroom permit teachers a flexible opportunity to contact parents from their classrooms when learners are not present. Use of voice mail to augment phone communication has been specifically explored to enhance communication opportunities with parents.

Internet technology is the most recent tool used by schools to communicate to a parent community. Increasingly, school websites are used to convey a broad message of school information. Learners often become involved with both the technology and the content of the website and may work together with teachers to create and maintain the site. Teachers trained to use the school website can provide updates easily accessed by parents regarding homework assignments, test schedules, and resource links. Use of the internet can serve as an interactive tool for individualizing homework and supporting the involvement of families in the homework process (Salend, Duhaney, Anderson, \& Gottschalk, 2004). Salend et al. (2004) notes that a homework website can start with a simple format providing basic information to parents and learners, and gradually increase in sophistication to create electronic assignment logs and individualized homework modifications for learners, incorporating appropriate password protection. Technology also holds promise to allow teachers communication opportunities not limited by school hours or location. Learners' performances can be videotaped and presented to a larger audience at convenient times. Learners may create digital portfolios that can be shared with parents on an ongoing basis. Ultimately, learners' learning plans may be accessed online, enabling goals and progress to be shared with parents. The capacity to link homes and schools with new technologies provides many novel opportunities to enhance communication with parents beyond the traditional formats.

\section{Methodology of research}

The general aim of the research is to examine, critically analyze and interpret attitudes and opinions of elementary teachers and parents about their cooperation and communication strategies in primary schools in the Republic of North Macedonia.

\subsection{Research questions}

$>\quad$ Which communication strategies are used by teachers and parents in primary schools?

$>\quad$ What is the level of parental involvement in making important questions from school life?

$>\quad$ What are the most common reasons that make communication between teachers and parents difficult?

\subsection{Methods and techniques of research}

The research was conducted with a descriptive - analytical method that is adequate and in accordance with the nature and character of the set goals of the research. The analytical method analyzed the views and opinions of the respondents covered in the sample of the research. The research was carried out using a questionnaire for both teachers and parents. Questionnaires contained a combination of closed and open type question and Likert Scales. 


\subsection{Sample of research}

The sample of the research consists of teachers and parents from 10 primary schools in the Republic of North Macedonia. The sample was chosen randomly in each of the 10 primary schools. The sample of the research was consisted of 50 teachers and 371 parents.

\subsection{Data processing}

The data were processed quantitatively and qualitatively using the EXCEL and STATISTICS computer programs. The data were grouped according to the number of matching in certain categories and then placed in tables. The data were calculated with frequencies for which a percentage was calculated. The following statistical procedures were used in the processing of data:

1. Chi - square test $\left(x^{2}\right)$ to determine whether the differences observed statistically are significant at a certain level of significance. To accept the hypothesis, the calculated values of Chi - square test must be less than the critical values. The critical values of Chi - square test depend on the number of degrees of freedom (df) and the level of significance or risk which is usually $5 \%$ or $1 \%$. $\left(\mathrm{P}_{0.05}, \mathrm{P}_{0.01}\right)$.

2. Contingency coefficient (C) to determine the degree of connection between the variables. The value of the Contingency coefficient is in the interval $0 \leq \mathrm{C} \leq 1$ and if it is closer to 1 , then the relationship between the observed features is stronger.

\section{Results and discussion}

\section{Research Question no. 1:}

Which communication strategies are used by teachers and parents in primary schools?

Table 1 presents the attitudes of teachers and parents regarding the mutual communication strategies.

\section{Table 1}

Communication strategies used by teachers and parents

\begin{tabular}{|c|c|c|c|c|c|c|c|c|c|c|c|}
\hline \multirow[t]{2}{*}{ Communication strategies } & \multicolumn{2}{|c|}{$\begin{array}{c}\text { Very } \\
\text { often } \\
\% \\
\end{array}$} & \multicolumn{2}{|c|}{$\begin{array}{c}\text { Often } \\
\%\end{array}$} & \multicolumn{2}{|c|}{$\begin{array}{c}\text { Rarely } \\
\%\end{array}$} & \multicolumn{2}{|c|}{$\begin{array}{c}\text { Never } \\
\%\end{array}$} & \multirow{2}{*}{$\begin{array}{c}\text { Total } \\
\% \\
\mathrm{P} / \mathrm{T}\end{array}$} & \multicolumn{2}{|c|}{$\begin{array}{c}\mathrm{df}=3 \\
\mathrm{P}_{0.05}=7.82 \\
\mathrm{P}_{0.01}=11.34\end{array}$} \\
\hline & $\mathrm{P}$ & $\mathrm{T}$ & $\mathrm{P}$ & $\mathrm{T}$ & $\mathrm{P}$ & $\mathrm{T}$ & $\mathrm{P}$ & $\mathrm{T}$ & & $y^{2}$ & C \\
\hline Teachers - parents school meetings & 29 & 26 & 56 & 70 & 15 & 4 & 0 & 0 & 100 & 5.67 & 0.12 \\
\hline $\begin{array}{l}\text { Written evaluative information regarding } \\
\text { learner progress }\end{array}$ & 40 & 30 & 33 & 66 & 19 & 2 & 8 & 2 & 100 & 24.2 & 0.23 \\
\hline $\begin{array}{l}\text { Teachers provide information about the } \\
\text { curriculum }\end{array}$ & 37 & 24 & 17 & 22 & 21 & 34 & 25 & 20 & 100 & 110.97 & 0.46 \\
\hline $\begin{array}{l}\text { Teachers provide information about school } \\
\text { events and extracurricular activities }\end{array}$ & 49 & 40 & 21 & 30 & 17 & 18 & 13 & 12 & 100 & 157 & 0.52 \\
\hline Sending a school newspaper to the parents & 47 & 11 & 4 & 9 & 14 & 42 & 35 & 38 & 100 & 287.68 & 0.91 \\
\hline Teachers visit the parents' home & 4 & 2 & 3 & 14 & 8 & 16 & 85 & 68 & 100 & 39.5 & 0.29 \\
\hline $\begin{array}{l}\text { Questionnaires with parents to examine their } \\
\text { views }\end{array}$ & 7 & 4 & 10 & 20 & 28 & 44 & 55 & 32 & 100 & 15.56 & 0.19 \\
\hline $\begin{array}{l}\text { Organizing Open days for parents in the } \\
\text { school and the opportunity to attend classes }\end{array}$ & 8 & 8 & 6 & 10 & 12 & 42 & 74 & 40 & 100 & 59.35 & 0.35 \\
\hline $\begin{array}{l}\text { Organizing educational and counseling } \\
\text { workshops with parents }\end{array}$ & 8 & 6 & 8 & 22 & 23 & 44 & 61 & 28 & 100 & 42.9 & 0.30 \\
\hline
\end{tabular}

The attitudes of parents regarding the frequency of using certain communication strategies, show that the highest percentage of parents chose the modality "never" for home visits by teachers (85\%), questionnaires with parents to examine their views (55\%), organizing Open days in the school and the opportunity to attend classes 
(74\%), as well as organizing educational and counseling workshops with parents (61\%). The most common communication strategies according to the views of parents apesending a written form of child evaluation, sending information about the curriculum, sending information about school events and extracurricular activities, sending a school newspaper and teachers - parents school meetings. The results show that one-way communication is most often used, as opposed to two-way communication between parents and teachers.

In order to determine whether there are differences in the attitudes of parents and teachers about the achieved communication strategies and whether they are statistically significant, we use the $y^{2}$ test. From the table we can clearly see that there are significant differences in the attitudes of parents and teachers about the use of certain communication strategies, and the calculated $\chi^{2}\left(\mathrm{df}=3, \mathrm{P}_{0.05}=7.82, \mathrm{P}_{0.01}=11.34\right)$ shows that these differences are statistically significant, with the exception of teachers - parents school meetings as one of the most practiced traditional models of communication.

Effective communication is essential to create strong school-home partnerships and to increase parental involvement. Just as teachers are skilled in the art of teaching, they also require knowledge and skills to effectively communicate with their parent community. A number of communication opportunities are currently available to teachers, ranging from school-to-home communication books to parent conferences to the use of internet technology. Teachers should strive to use a variety of effective strategies to make communication with parents as informative and interactive as possible, incorporating new communication methods and yet retaining the human touch. Every communication exchange, regardless of its form, should reflect a thoughtful, planned approach and should be viewed as an opportunity for teachers to promote parent partnerships and ultimately, to support student learning.

\section{Research Question no. 2:}

What is the level of parental involvement in making important questions from school life?

Turning from the matter of parent involvement in children's learning, what about the outcomes produced by parent involvement in important questions from school life? This includes any activity which provides parents the opportunity to take part in the decision making about school programs. Areas in which parents may be helping to make program decisions include goal setting, development and implementation of program activities, assessment, personnel decisions, and funding allocations.

\section{Table 2}

Influence and involvement of parents in bringing important issues from school life

\begin{tabular}{|c|c|c|c|c|c|c|c|c|c|c|c|}
\hline \multirow[t]{2}{*}{$\begin{array}{l}\text { Influence and involvement of parents in } \\
\text { bringing important issues from school life }\end{array}$} & \multicolumn{2}{|c|}{$\begin{array}{l}\text { A Lot } \\
\%\end{array}$} & \multicolumn{2}{|c|}{$\begin{array}{c}\text { Enough } \\
\%\end{array}$} & \multicolumn{2}{|c|}{$\begin{array}{l}\text { Little } \\
\%\end{array}$} & \multicolumn{2}{|c|}{$\begin{array}{l}\text { Never } \\
\%\end{array}$} & \multirow{2}{*}{$\begin{array}{c}\begin{array}{c}\text { Total } \\
\%\end{array} \\
\mathrm{P} / \mathrm{T}\end{array}$} & \multicolumn{2}{|c|}{$\begin{array}{c}\mathrm{df}=3 \\
\mathrm{P}_{0.05}=7.82 \\
\mathrm{P}_{0.01}=11.34\end{array}$} \\
\hline & $\mathrm{P}$ & $\mathrm{T}$ & $\mathrm{P}$ & $\mathrm{T}$ & $\mathrm{P}$ & $\mathrm{T}$ & $\mathrm{P}$ & $\mathrm{T}$ & & $x^{2}$ & $C$ \\
\hline $\begin{array}{l}\text { Parents have the opportunity to influence the } \\
\text { on teaching and learning activities }\end{array}$ & 1 & 2 & 18 & 10 & 20 & 38 & 61 & 50 & 100 & 9.12 & 0.15 \\
\hline $\begin{array}{l}\text { Parents have the opportunity to take part in } \\
\text { decision making about school programs. }\end{array}$ & 1 & 2 & 17 & 10 & 23 & 20 & 59 & 78 & 100 & 2.31 & 0.07 \\
\hline $\begin{array}{l}\text { Parents are involved in designing the child's } \\
\text { extracurricular activities }\end{array}$ & 10 & 4 & 38 & 52 & 18 & 28 & 34 & 16 & 100 & 10.92 & 0.16 \\
\hline $\begin{array}{l}\text { Parents are involved in solving the child's } \\
\text { disciplinary problems }\end{array}$ & 11 & 38 & 36 & 44 & 13 & 12 & 40 & 6 & 100 & 38.17 & 0.29 \\
\hline
\end{tabular}

The answers of the parents show that many of them no or a little have Influence of bringing important issues from school life. A smaller percentage of parent's thing that they are a lot or enough involved in making important school decisions. Teachers' answers show that parents are more involved in solving child's disciplinary problems and designing extracurricular activities, but have little or no influence when it comes to their participation in making important decisions about school and teaching. Calculated $x^{2}\left(\mathrm{df}=3, \mathrm{P}_{0.05}=7.82\right.$, 
$\mathrm{P}_{0.01}=11.34$ ) shows that there are statistically significant differences in the opinions of parents and teachers about the influence and the involvement of parents in solving a child's disciplinary problems and designing extracurricular activities.

Most countries make available to parents a number of opportunities for participating in schools and policy making (serving in school governing boards is required in some countries) as well as regulations and mechanisms for voicing their concerns in case of a decline in the quality of education their children receive (there may be a formal process in place for filing complaints, an ombudsman or a designated agency for complaints and grievances). Typical barriers to increased parental involvement in schools are time constraints among parents; lack of awareness of opportunities to engage; and lack of communication between school staff and parents. The extent of involvement may also differ between parents depending on their background, which may, therefore, increase inequities in education.

\section{Research Question no.3:}

What are the most common reasons that make communication between teachers and parents difficult?

Respondents were asked what the most common reasons that make it difficult for them to communicate with each other are. We will point out the most common reasons that were confirmed by both teachers and parent's:

$>$ Harmonization of the working hours of the teacher and the parent's;

$>\quad$ The impartiality of the parents when it comes to their child, above all about the difficulties that their children have;

$>$ Distrust and concealment of problems.

$>$ Greater education of both teachers and parents in order to learn something more about mutual cooperation;

$>\quad$ Insufficient organization of workshops and design of joint activities in order to show parents that they are also an important segment in school life;

$>\quad$ Insufficient skills to use Internet technology and online communication.

Table 3

Attitudes about mutual cooperation and communication

\begin{tabular}{|c|c|c|c|c|c|c|c|}
\hline $\begin{array}{c}\text { How satisfied are you with the } \\
\text { mutual cooperation and } \\
\text { communication? }\end{array}$ & $\begin{array}{c}\text { Very } \\
\text { satisfied \% }\end{array}$ & $\begin{array}{c}\text { Satisfied } \\
\%\end{array}$ & $\begin{array}{c}\text { Partially } \\
\text { satisfied \% }\end{array}$ & $\begin{array}{c}\text { Dissatisfied } \\
\%\end{array}$ & $\begin{array}{c}\text { Total } \\
\%\end{array}$ & \multicolumn{2}{|c|}{$\begin{array}{c}\mathrm{df}=3 \\
\mathrm{P}_{0.05}=7.82 \\
\mathrm{P}_{0.01}=11.34\end{array}$} \\
\hline Parents & 23 & 59 & 16 & 2 & 100 & $x^{2}$ & $C$ \\
\hline Teachers & 20 & 60 & 12 & 8 & 100 & 5.97 & 0.13 \\
\hline
\end{tabular}

The calculated $y^{2}=5.97\left(\mathrm{df}=3, \mathrm{P}_{0.05}=7.82, \mathrm{P}_{0.01}=11.34\right)$ shows that the differences in the opinions of parents and teachers about mutual cooperation and communication are not statistically significant, most of the parents and teachers are satisfied with the mutual cooperation.

The results show that most teachers are satisfied with the cooperation with the parents, and are certainly realistic when they point out that an ideal situation can't be expected, but it can be improved through greater education on both sides. They point out that parents often leave the whole initiative to them, but there are cases when the desire of parents to impose their influence on the work of the school, with the attitude that "they know more" disrupts the cooperative relations. Because these are young students, it is impossible to complete schoolwork without the help of parents, so they are often present at the school and are interested in their children's progress, teachers say. Parents are aware of the importance and significance of mutual cooperation so 
that there are no major barriers and obstacles to the implementation of this concept. Good organization and greater motivation are needed for both teachers and parents.

\section{Conclusions and recommendations}

The research conducted on 371 parents and 50 teachers from the primary schools in the Republic of North Macedonia, showed that parents and teachers are satisfied with their mutual cooperation. Although both believe that the cooperation between the school and the family will improve if different communication strategies are used. The traditional ones are still dominant, one-way communication dominates, and the direct participation of parents and their feedback in the organization and realization of school events and activities is neglected. The ways of communication are primarily aimed at transmitting information to parents, and less common are those that provide an opportunity for active engagement of parents, using their knowledge, skills and experiences as an important resource that can contribute to school openness and building partnership with the school.

Everyday reality shows that the amount of time that parents and children spend together during the day is getting shorter. Almost all parents are able to constantly balance between their own work tasks and the needs of the family. The pressure they feel from the struggle for financial survival makes them less able to participate in the lives of their own children, which means that they are not aware of or do not see the great need for it. Schools must therefore meet the needs of parents and students and involve parents in their children's school life. The involvement of parents in the work of the school is of great importance for both students and parents, as well as for the school, and given that it works in the local environment, it is also important for the community and beyond. The results showed that parents are often informed about what is expected of their child in each subject, but are not sufficiently informed about how to help the child perform his or her schoolwork and how to help the child develop and improve certain learning skills. When it comes to the influence of parents in bringing important issues from school life, both parents and teachers are unanimous. The results show that the largest number of parents can't or very little can influence the current issues of school life, especially the teaching and curriculum. The answers of the parents are another confirmation of the centralization of the curriculum in the schools, where there is no flexible adaptation of the curriculum to the specifics of the school, in the creation of which the parents should have a significant role. In other words, parents are not yet active participants and partners in the process of educating their children. This research shows that there is an interest in such a partnership, and there are numerous ways to encourage it.

The data from our research showed that there is a large number of parents who want to contribute more, but do not know how. More than half of the parents reported that teachers rarely suggest ways to get involved in a school activity. The school can help in the several ways.

School can encourage parents to be actively involved in the process of educating their children in the following ways:

$>$ teachers should be informed about the knowledge, skills, interests of parents and examine how they can contribute to teaching, extracurricular activities and overall school life;

$>$ the school can organize workshops and lectures on topics about child development, ways of learning and the help that parents can give to their children;

$>$ the school can encourage parents to express their own interests and hold workshops on topics they find useful;

$>$ the development of an action plan that will be jointly devised during the year.

The school can encourage the exchange of experiences between parents. The dialogue between the parents themselves can have a motivating effect on those parents who do not show sufficient readiness to cooperate with the school. The school can be a significant basis and source of parental support by: 
Communication strategies for strengthening the parent-teacher relationships in the primary schools

$>$ Expanding the possibility of exchanging experiences between parents, for example, within parent meetings;

$>$ Giving opportunities for parents to self-organize and hold informal meetings in the school premises;

$>$ Equipping school libraries with appropriate literature that will enrich the knowledge and experience of parents.

The school can start a dialogue with the parents about their participation in the decision-making process. The results show that parents have very little influence in making decisions about certain aspects of school life. It is suggested that parents and teachers engage in dialogue about their own expectations and attitudes related to parental involvement in the school decision-making process. A dialogue is a good basis for understanding the needs, harmonizing mutual expectations, sharing responsibilities and establishing a true partnership.

The school can provide quality support to teachers in fostering partnerships with parents. The most commonly cited reasons for insufficient cooperation are parents' lack of time, as well as lack of training and communication skills. This requires training of parents and raising their awareness of the benefits of their participation in the education process. But above all, training is needed for the teachers and the other school staff. Their task is much more difficult because they have to be both planners and organizers and implementers of the whole process. When parents are partners with the school, they not only help their children's learning process, but also bring a life reality into the learning environment that gives learning the necessary meaning. Building partnerships between parents and teachers, for the children, the future citizens, is a model of democratic behavior.

\section{References}

Aronson, M. M. (1995). Building communication partnerships with parents. Westminster, CA: Teacher Created Materials, Inc.

Bender, Y. (2005). The tactful teacher. Effective communication with parents, colleagues, and administrators. United States: Normad Press.

Caspe, M. S. (2003). How teachers come to understand families. The School Community Journal, 13(1), 115-131. Retrieved from https://www.adi.org/journal/ss03/caspe\%20115-132.pdf

Chambers, L. (1998). How customer-friendly is your school? Educational Leadership, 56(2), 33-35.

Davern, L. (2004). School-to-home notebooks: What parents have to say. Council for Exceptional Children, 36(5), 22-27. https://doi.org/10.1177\%2F004005990403600503

Dembo, M. H., \& Gibson, S. (1985). Teachers' sense of efficacy: An important factor in school improvement. The Elementary School Journal, 86, 173-184. https://doi.org/10.1086/461441

Epstein, J. L., \& Van Voorhis, F. L. (2001). More than minutes: Teachers' roles in designing homework. Educational Psychologist, 36(3), 181-193. https://doi.org/10.1207/S15326985EP3603_4

Epstein, J. (1995). School/family/community partnerships: Caring for the children we share. Phi Delta Kappan, 76(9), 701-712. https://doi.org/10.1177/003172171009200326

Fuller, C. (1999). Helping your child succeed in public school. From kindergarten to high school (2nd Edition) Illinois: Tyndale.

Grolnick, W., \& Slowiaczek, M. (1994). Parents' involvement in children's schooling: A multidimensional conceptualization and motivational model. Child Development, 65(1), 237-252. https://doi.org/10.2307/1131378

Giannetti, C. C., \& Sagarese, M. M. (1998). Turning parents from critics into allies. Educational Leadership, 55(8), 40-42.

Hoover-Dempsey, et al. (2005). Why do parents become involved? Research findings and implications. The Elementary School Journal, 106(2), 105-130. https://doi/10.1086/499194

Hong, S., \& Ho, H.Z. (2005). Direct and indirect longitudinal effects of parent involvement on student 
achievement: Second-order latent growth modelling across ethnic groups. Journal of Educational Psychology, 97(1), 32-42. https://doi.org/10.1037/0022-0663.97.1.32

Hill, N., \& Taylor, L. (2004). Parental school involvement and children's academic achievement. American Psychological Society, 13(4), 161-164. https://doi.org/10.1111/j.0963-7214.2004.00298.x

Kaiser, A., \& Delaney, E. (1996). The effects of poverty on parenting young children. Peabody Journal of Education, 71(4), 66-85.

Lawrence-Lightfoot, S. (2003). The essential conversation: What parents and teachers can learn from each other. New York: Random House.

Lai, Y., \& Ishiyame, F. I. (2004). Involvement of immigrant Chinese Canadian mothers of children with disabilities. Exceptional Children, 71(1), 97-108.

Love, F. E. (1996). Communicating with parents: What beginning teachers can do. College Student Journal, 30(4), 440-444.

McNeal, Jr., \& Ralph, B. (1999). Parental involvement as social capital: Differential effectiveness on science achievement, truancy, and dropping out. Social Forces, 78(1), 117-144. https://doi.org/10.2307/3005792

Metcalf, L. (2002). The parent conference: An opportunity for requesting parental collaboration. Canadian Journal of School Psychology, 17(1), 17-25. https://doi.org/10.1177/082957350201700103

Minke, K. M., \& Anderson, K. J. (2003). Restructuring routine parent-teacher conferences: The family-school conference model. The Elementary School Journal, 104(1), 49-69. https://doi.org/10.1086/499742

Ozmen, F., Akuzum, C., Zincirli, M., \& Selcuk, G. (2016). The communication barriers between teachers and parents in primary schools. Eurasian Journal of Educational Research, 66, 26-46. https://doi.org/10.14689/ejer.2016.66

Salend, S. J., Duhaney, D., Anderson, D. J., \& Gottschalk, C. (2004). Using the internet to improve homework communication and completion. Teaching Exceptional Children, 36(3), 64-73.

Shpancer, N. (1997). The link between caregiver-parent relations and children's experiences in daycare and at home: What does the research tell us? Early Child Development and Care, 135(1), 7-20. https://doi.org/10.1080/0300443971350102

Ramirez, F. (2001). Technology and parent involvement. Clearing House, 75(1), 30-31. https://doi.org/10.1080/00098650109599230

Ripley, A. (2010, January/February). What makes a great teacher? The Atlantic. Retrieved from https://www.theatlantic.com/magazine/archive/2010/01/what-makes-a-great-teacher/307841/

Schussler, D. L. (2003). Schools as learning communities: Unpacking the concept. Journal of School Leadership, 13(3), 498-528. https://doi.org/10.1177/105268460301300501

Vandergrift, J., \& Greene, A. (1992, September). Rethinking parent involvement. Educational Leadership, 50(1), 57-59. 